
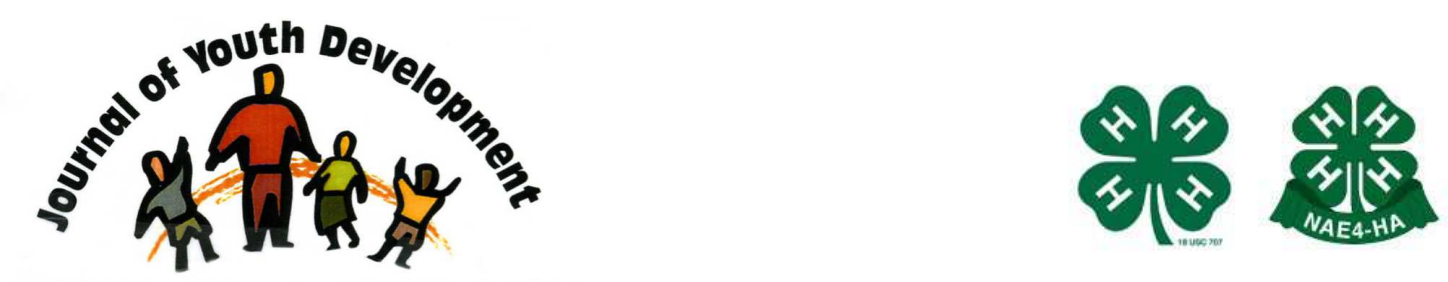

Bridging Research \& Practice

\title{
The Career Maturity of 4-H Healthy Lifestyles Program Participants
}

\author{
Courtney F. Dodd \\ Texas A\&M AgriLife Extension Service \\ College Station, TX \\ cfdodd@ag.tamu.edu \\ Summer F. Odom \\ Texas A\&M University \\ College Station, TX \\ summerodom@tamu.edu \\ Christopher T. Boleman \\ Texas A\&M AgriLife Extension Service \\ College Station, TX \\ Chris.boleman@agnet.tamu.edu
}




\title{
JOURNAL OF YOUTH DEVELOPMENT \\ bridging research and practice

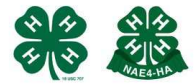

Bridging Research \& Practice

Volume 9, Number 3, Fall 2014

Article 140903FA003

\section{The Career Maturity of 4-H Healthy Lifestyles Program Participants}

\author{
Courtney F. Dodd, Summer F. Odom and Christopher T. Boleman \\ Texas A\&M University
}

\begin{abstract}
This study examined the readiness of youth involved in the 4-H healthy lifestyles program to make career decisions, identified as career maturity. A random sample of youth involved in the 4- $\mathrm{H}$ healthy lifestyles program was used to participate in the research study, which entailed the completion of an online survey. The findings indicate that youth in the 4-H healthy lifestyles program have a high level of career maturity with some significant differences found based upon age; however, no significant differences were found based upon gender or years of involvement in the 4-H program.
\end{abstract}

\section{Introduction}

Young people need to be connected to programs, services, activities, and a support system that helps them learn about the various options available after completing school. Such career preparation and work-based learning experiences are essential for youth to develop aspirations and make informed choices about careers (Department of Labor, 2013a). According to the United States Department of Labor (2013b), all youth need information on career options, including

- Career assessments to help identify youths' school and post-school preferences and interests

- Structured exposure to post-secondary education and other life-long learning opportunities

- Exposure to career opportunities, including information about educational and entry requirements

- $\quad$ Training designed to improve job-seeking skills and work-place basic skills.

Exposure to career options is a major component of the Texas 4-H Youth Development Program and can help youth develop career maturity. 


\section{4-H and Career Development}

The Texas 4-H Youth Development Program gives youth the opportunity to explore a wide variety of project areas. Within the positive learning experiences offered through each 4-H project youth are also given the opportunity to explore higher education and career opportunities which may influence future life decisions.

Various studies have identified the positive impact 4-H involvement has had on the choice of and success with one's career. Williams, et al. (2010) discovered that long-term participation in the 4-H Youth Development Program, such as 4-H community clubs and after-school programming, has a positive impact on the career choice of youth ages 14-19. Their findings indicated that 4- $\mathrm{H}$ exposes youth to specific careers and occupational experiences. However, the results also demonstrate that youth in 4-H learn about careers not only through participation in 4-H but also through non-4-H activities.

In another research study, alumni perceived the greatest impact of $4-\mathrm{H}$ to be general career awareness concerning recognition of interests and abilities leading to a career, knowledge of career exploration resources, career considerations, and a sense of need to make a career choice (Matulis, Hedges, Barrick, \& Smith, 1988).

Rockwell, Stohler and Rudman (1984) studied a sample of Nebraska 4-H alumni to determine how they felt 4- $\mathrm{H}$ helped them select a career and assume adulthood roles 10 to 20 years after their 4-H experiences. It was found that 4- $\mathrm{H}$ activities and people involved with leading the 4-H program, including 4- $\mathrm{H}$ leaders and Extension Agents, influenced their choice of a career. As youth remained in 4-H over a longer period of years, they were more likely to indicate that 4-H influenced their choice of an area of study or their selection of an institution of higher education.

\section{Career Maturity}

Career exploration has been noted as a prerequisite to achieving career maturity (Ochs, \& Roessler, 2004), which is one aspect of career development (Super, 1990). Being career mature implies that an individual is able to accomplish the tasks that are appropriate for his or her age and stage of development (Brown, \& Lent, 2005).

According to Super (1990), career maturity is defined as "an individual's readiness to cope with the developmental tasks for that stage of development" (p. 213). It involves an individual's ability to make appropriate career choices, including awareness of what is required to make a career decision and the degree to which one's choices are both realistic and consistent over time (King, 1989; Ohler, Levinson, \& Hays, 1996).

Career maturity has also been referred to as the extent to which an individual has acquired the necessary knowledge and skills to make intelligent, realistic career choices. It is the readiness of an individual to make an informed, age-appropriate career decision and cope with appropriate career development tasks (Luzzo, 1993; Savickas, 1984).

Career maturity can be broken down into stages, along a continuum, classified as exploratory, establishment, maintenance, and decline stages. Adolescents are in what is called an exploratory stage of career maturity, which is made up of sub-stages, including and described by Super (1955) and Crites (1973) as: 
- Orientation to vocational choice: This stage involves one being concerned with making a choice and developing awareness that a choice needs to be made and what factors may influence the choice.

- Information and planning about preferred occupation: Within this sub-stage, adolescents are acquiring specific information about their preferred occupation, such as the requirements, duties, work conditions and opportunities. Mapping out a plan for what needs to be accomplished in high school, post-high school and entry into the profession is also explored.

- Increasing consistency of vocational preferences: Adolescents within this sub-stage are developing consistency with their preferences over time. Their vocational preferences are also becoming more consistent within an occupational field.

- Crystallization of traits relevant to vocational choices: Adolescents developing career maturity will begin to more clearly define their interests and accept the responsibility they have to make a career choice.

- Increasing wisdom of vocational preferences: In this sub-stage, viewed as the most complex and difficult to manage yet most satisfying, a relationship among one's activities, abilities, interests and preferences is formed as the adolescent gains knowledge of his or her accessibility of their preferred occupation.

A variety of research studies have focused on the numerous correlates of career maturity, including age (Stern, Norman, \& Zevon, 1991) and gender (King, 1989; King, 1990; Patton, \& Creed, 2001), as well as personal characteristics, such as self-esteem (Ohler, Levinson, \& Sanders, 1995). While various researchers have discovered girls to show more career maturity at a given age than boys (Omvig, \& Thomas, 1977; Westbrook, Cutts, Madison, \& Arcia, 1980), Erol and Orth (2011) found male adolescents to have higher self-esteem than female adolescents.

Patton and Creed (2001) found developmental differences with 15-17 year olds scoring higher on career maturity attitude and knowledge than the 12-14 year olds. King (1989) found that while age was the most important determinant of career maturity for boys, a sense of family cohesion and an internal locus of control were the main determinants for girls.

Because of the role the 4-H Youth Development Program plays in the career development of youth, it is important to examine the impact if any, involvement in the 4-H program has on the development of youths' career maturity.

\section{Purpose and Objectives}

The purpose of this study was to examine the readiness of youth involved in the 4-H healthy lifestyles program to make career decisions, identified as career maturity. The study was guided by the following objectives:

1. Determine the career maturity level of youth involved in the 4-H healthy lifestyles program.

2. Explore gender differences in career maturity of youth involved in the 4-H healthy lifestyles program.

3. Compare the career maturity of youth involved in the 4-H healthy lifestyles program based upon age.

4. Assess if there is a relationship between the career maturity of youth involved in the 4-H healthy lifestyles program based upon the number of years in $4-\mathrm{H}$. 


\section{Methodology}

Healthy living has been a part of the 4- $\mathrm{H}$ and Youth Development Program since its inception in 1902 (4-H National Headquarters, 2011). On the national level, the 4-H Healthy Living Mission Mandate "engages youth and families through access and opportunities to achieve physical, social, and emotional well-being" (4-H National Headquarters, 2011, p. 1). In Texas, the healthy lifestyles program encompasses the food and nutrition, health and safety projects (Texas 4-H \& Youth Development, 2013b). Through involvement in these projects, youth are given the opportunity to participate in educational activities, career camps, contests, and serve in leadership positions.

\section{Population and Sample}

The target audience for this study was youth who met the following criteria

- Member of the Texas 4-H Youth Development Program in the current (2012-2013) year;

- Classified as a senior 4-H member (at least 14 years of age, but not 19 at the start of the 2012-2013 4-H year);

- Enrolled in at least one of the 4-H healthy lifestyles-related projects; and

- Have an e-mail address.

The online 4-H registration and enrollment management system used by the Texas 4-H program was used to determine 4-H members that met the criteria for the research study. The system stores contact information, demographics, as well as program involvement for each $4-\mathrm{H}$ member.

From the sampling frame of 2,590 youth, a random sample of 350 4- $\mathrm{H}$ members was selected to participate in the research study, representing 155 counties.

\section{Instrumentation}

The Career Maturity Inventory (CMI) Counseling Form $\mathrm{C}$ was used to assess the maturity of 4-H members enrolled in the 4-H healthy lifestyles program. The original CMI was developed to assess career attitudes and competencies of children and adolescents in grades 5-12 and was the first paper-and-pencil measure of vocational development used to measure a student's readiness to make occupational choices (Savickas, \& Porfeli, 2011). Savickas and Porfeli (2011) point out that pertaining to the CMI as youths' ability to adapt increases, so too does their general readiness to make realistic occupational choices.

The instrument consists of 24 statements about choosing the kind of job or work one will probably do when they finish school, to which respondents either agree or disagree, earning a point for each statement answered correctly. The instrument is made up of four sub-scales, each consisting of six statements, and produces five different scores:

- CCC score: This total score for career maturity is based on the 18 items in the concern, curiosity and confidence scales.

- Concern: The extent to which an individual is oriented to and involved in the process of making career decisions. Becoming aware of choices that must be made in the immediate and intermediate future is the first step in the career decision-making process.

- Curiosity: The extent to which an individual is exploring the work world and seeking information about occupations and their requirements. Confusion about the career decision-making process can be minimized when one explores their own abilities and interests along with occupations that fit the individual's personality and talents. 
- Confidence: The extent to which an individual has faith in his or her ability to make wise career decisions and realistic occupation choices. When one is confident in the career decision-making process it means he or she can anticipate being successful in overcoming challenges and problems he or she may encounter.

- Consultation: This score measures the extent to which an individual seeks assistance in career decision-making by requesting information or advice from others. The score for these six questions are not included in the total adaptability score in recognition of one's preference to consult significant people in their lives while others choose to make decisions on their own (Savickas, \& Porfeli, 2011).

In a research study conducted by Savickas and Porfeli (2011), the coefficient alpha for the CMI Form $\mathrm{C}$ total score was .86. The authors of this research study ran a Cronbach Coefficient Alpha reliability coefficient, which was calculated to be .82 .

\section{Data Collection and Analysis}

Data collection was performed using an online instrument with the researcher following the guidelines for web survey implementation proposed by Dillman, Smyth, and Christian (2009). This included recruitment and follow-up e-mails delivered to participants after one, two and three weeks, which included a link to the online survey. Since the responses were anonymous, the researcher could not follow-up solely with non-respondents. After three weeks, an e-mail was sent by the state $4-\mathrm{H}$ leader, endorsing the research study and encouraging participation. A final reminder was sent to all participants one week later, notifying them of the final day to complete the survey and provide feedback. The survey was closed after being open for four and one-half weeks.

Due to a low response rate (28.5\%) after four and one-half weeks, additional measures were taken to increase participation. The researcher used procedures outlined by Lindner, Murphy, and Briers (2001), specifically using method three to compare early respondents with laterespondents. Phone calls were made to all participants in the random sample to introduce and remind youth about the research study and asked if they had completed the survey. After phone calls were placed, one final reminder was e-mailed to all participants about the survey with one final opportunity to complete it. This process resulted in an additional 70 (20\%) participants responding to the online survey, which is greater than the minimum of 30 responses recommended by Lindner, et al. (2001).

The results of an independent samples $t$-test did not reveal any significant differences between early respondents and late respondents at the $p<.05$ level.

\section{Findings}

\section{Profile of Participants}

Of the 127 complete and usable responses, 91 (71.1\%) were female and $36(28.3 \%)$ were male. The mean age of participants was 15.91 years $(S D=1.21)$ with ages ranging from 14 to 18 years and grades nine through 12 represented. The average years in 4- $\mathrm{H}$ among the 127 participants was 7.43 years with responses ranging from one year to 10 years with the most frequented response being eight years.

\section{Objective One}

The first objective was to determine the career maturity level of youth involved in the 4-H healthy lifestyles program. The overall mean score on the CMI was calculated at 17.94 
$(S D=4.21, n=127)$. Career maturity scores were calculated for each of the sub-scales of the CMI, as well as the CCC score, which is based on the sum of the concern, curiosity and confidence sub-scales, as noted by Savickas and Porfeli (2011). Participants ranked highest for the sub-scale of concern, which is the first step in the career decision-making process (Savickas, \& Porfeli, 2011). Although the lowest sub-scale was confidence, the participants still outscored the high school norm.

When compared to the study provided by Savickas and Porfeli (2011). More to the point, it is evident that the 4-H members scored higher on three of the four sub-scales. Participants scored lower than the high school norm on the consultation construct. Career Maturity Inventory scores are presented and compared to the high school norms in Table 1.

Table 1

Rank Order of Career Maturity Inventory Sub-Scale Mean Scores $(N=127)$

\begin{tabular}{|lcccc|}
\hline Sub-Scale & Mean & SD & Norm Mean $^{c}$ & Norm SD $^{c}$ \\
\hline CCC $^{\mathrm{a}}$ & 13.65 & 4.01 & 9.88 & 1.28 \\
Concern $^{\mathrm{b}}$ & 5.39 & 1.13 & 4.6 & 1.4 \\
Curiosity $^{\mathrm{b}}$ & 4.79 & 1.72 & 2.72 & 2.56 \\
Consultation $^{\mathrm{b}}$ & 4.31 & 1.50 & 4.94 & 1.4 \\
Confidence $^{\mathrm{b}}$ & 3.46 & 1.96 & 2.56 & 1.97 \\
\hline
\end{tabular}

a Score range was 0 to 18 .

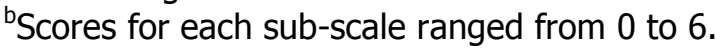

${ }^{\mathrm{C}}$ Mean scores and standard deviations provided by Savickas and Porfeli (2011).

\section{Objective Two}

To meet objective two, the researchers explored gender differences in career maturity of youth involved in the 4- $\mathrm{H}$ healthy lifestyles program. A $t$-test was calculated to determine if any significant differences existed between males and females for the scores associated with the CMI. Mean scores that were compared for gender include the total score, CCC, and then each of the four sub-scales.

The results are displayed in Table 2 and indicate that males outscored females on all scores except the concern sub-scale. Overall, the $t$-test did not reveal a significant difference $(p<.05)$ among males and females for any of the mean scores calculated. 
Table 2

Comparison of Career Maturity Inventory Scores by Gender

\begin{tabular}{|lccccccc|}
\hline \multicolumn{7}{c}{ Males } & \multicolumn{2}{c|}{ Females } \\
\hline Scale & Mean $^{\mathrm{a}}$ & SD & Mean $^{\mathrm{b}}$ & SD & $\boldsymbol{t}$-value & df & Sig. $^{\mathbf{c}}$ \\
\hline CMI Total $^{\mathrm{d}}$ & 18.53 & 4.58 & 17.73 & 4.06 & .968 & 125 & .335 \\
CCC $^{\mathrm{e}}$ & 14.08 & 4.21 & 13.47 & 3.94 & .963 & 125 & .442 \\
Concern $^{f}$ & 5.28 & 1.23 & 5.43 & 1.09 & -.678 & 125 & .499 \\
Curiosity $^{f}$ & 4.86 & 1.79 & 4.77 & 1.69 & .271 & 125 & .787 \\
Confidence $^{f}$ & 3.94 & 1.85 & 3.27 & 1.97 & 1.754 & 125 & .082 \\
Consultation $^{f}$ & 4.44 & 1.16 & 4.25 & 1.62 & .646 & 125 & .520 \\
\hline
\end{tabular}

${ }^{\mathrm{a}} \mathrm{n}=36$.

$\mathrm{b}_{\mathrm{n}}=91$.

'Significant at $\mathrm{p}<.05$.

${ }^{\mathrm{d} S}$ Score range was 0 to 24 .

${ }^{\mathrm{e}} \mathrm{S}$ core range was 0 to 18 .

fScore range was 0 to 6 .

\section{Objective Three}

The third objective involved the comparison of the career maturity of youth involved in the 4- $\mathrm{H}$ healthy lifestyles program based upon age. Analyses of variance (ANOVAs) were calculated with the dependent variable being the CMI mean scores and the independent variable being age, with a range of 14 to 19 . The results of the analyses are displayed in Table 3. The highest total mean score was the 18 year olds, followed by the 14 year olds. The lowest total mean score was for the 15 years olds, which indicates a drop in career maturity after age 14.

The ANOVA also revealed a significant difference $(p<.05)$ between age groups for the total score, CCC score, and the curiosity and confidence sub-scales. A REGWF post hoc analysis revealed that 18 year olds scored significantly higher than 15 year olds for the total score of the CMI. For the CCC score, as well as the curiosity and confidence constructs, the 15 and 16 year old participants scored significantly lower than 18 year olds at the $p<.05$ level. 
Table 3

Analysis of Variance for Career Maturity by Age

\begin{tabular}{|lccccccc|}
\hline \multicolumn{7}{c|}{ Mean Score by Age } \\
\hline & $\mathbf{1 4}$ years & $\begin{array}{c}\mathbf{1 5} \\
\text { years }\end{array}$ & $\mathbf{1 6}$ years & $\mathbf{1 7}$ years & $\begin{array}{c}\mathbf{1 8} \\
\text { years }\end{array}$ & $\mathbf{F}$ & Sig. \\
\hline & $\mathrm{n}=16$ & $\mathrm{n}=37$ & $\mathrm{n}=31$ & $\mathrm{n}=29$ & $\mathrm{n}=14$ & & \\
CMI Total $^{\mathrm{c}}$ & $18.88^{\mathrm{ab}}$ & $16.46^{\mathrm{a}}$ & $17.52^{\mathrm{ab}}$ & $18.45^{\mathrm{ab}}$ & $20.79^{\mathrm{b}}$ & 3.357 & .012 \\
CCC $^{\mathrm{d}}$ & $13.88^{\mathrm{ab}}$ & $12.43^{\mathrm{a}}$ & $12.90^{\mathrm{a}}$ & $14.48^{\mathrm{ab}}$ & $16.50^{\mathrm{b}}$ & 3.461 & .010 \\
Concern $^{\mathrm{e}}$ & $5.19^{\mathrm{a}}$ & $5.16^{\mathrm{a}}$ & $5.52^{\mathrm{a}}$ & $5.41^{\mathrm{a}}$ & $5.86^{\mathrm{a}}$ & 1.216 & .307 \\
Curiosity $^{\mathrm{e}}$ & $5.00^{\mathrm{ab}}$ & $4.41^{\mathrm{a}}$ & $4.35^{\mathrm{a}}$ & $5.14^{\mathrm{ab}}$ & $5.86^{\mathrm{b}}$ & 2.832 & .027 \\
Confidence $^{\mathrm{e}}$ & $3.69^{\mathrm{ab}}$ & $2.86^{\mathrm{a}}$ & $3.03^{\mathrm{a}}$ & $3.93^{\mathrm{ab}}$ & $4.79^{\mathrm{b}}$ & 3.584 & .008 \\
Consultation $^{\mathrm{e}}$ & $5.00^{\mathrm{a}}$ & $4.03^{\mathrm{a}}$ & $4.61^{\mathrm{a}}$ & $3.97^{\mathrm{a}}$ & $4.29^{\mathrm{a}}$ & 1.919 & .111 \\
\hline
\end{tabular}

${ }^{\mathrm{ab}}$ Means in rows having letter designations in common are not significantly different at the .05 level using Ryan-Einot-Gabriel-Welsch $\mathrm{F}$ (REGWF) post hoc analysis method.

'Scores rnage from 0 to 24 .

${ }^{\mathrm{d}}$ Scores range from 0 to 18 .

${ }^{\mathrm{e}} \mathrm{S}$ cores range from 0 to 6 .

\section{Objective Four}

For the final objective, the researchers sought to assess if there was a relationship between the career maturity of youth involved in the 4-H healthy lifestyles program based upon their number of years in 4-H. A Pearson product-moment correlation coefficient $(r)$ was calculated to determine the relationship between career maturity and years in $4-\mathrm{H}$, with results displayed in Table 4. Very low, positive correlations were found for the CMI total score and four of the five sub-scales that were not significant at the .05 level. A low, negative relationship was found for the consultation sub-scale, which also was not significant at the .05 level.

\section{Table 4}

Pearson Product Moment Correlation Coefficients for Career Maturity Inventory Scores and Years in 4-H

\begin{tabular}{|lcc|}
\hline Career Maturity & r & $\boldsymbol{p}^{*}$ \\
\hline CMI Total & .094 & .29 \\
CCC & .159 & .08 \\
Concern & .076 & .40 \\
Curiosity & .075 & .40 \\
Confidence & .132 & .14 \\
Consultation & -.050 & .57 \\
\hline
\end{tabular}

*Significant at the .05 level. 


\section{Conclusions}

In this study, the CMI was used to measure the readiness of youth involved in the 4-H healthy lifestyles program to make decisions about career choices. The participants' CMI scores were also compared based upon gender, age, and years of involvement in the 4-H program.

Based upon the findings of this study, the researchers concluded that the duration of youths' involvement in the Texas 4-H healthy lifestyles program does not have an impact on their career maturity. Aside from the years in $4-\mathrm{H}$, the results revealed that the youth involved in this study were career mature.

Differences in career maturity based upon gender also lacked significance. Males outscoring females on all scores except the concern sub-scale is consistent with research indicating adolescent males have higher self-esteem than females (Erol, \& Orth, 2011). This is important for youth development professionals to know, realizing what factors are most important in the development of career maturity based upon gender, especially the varying levels of self-esteem among males and females (King, 1989).

Researchers discovered a significant difference in career maturity between 18 and 15 year olds for the total score of the CMI. Fifteen and 16 year olds also scored significantly lower than 18 years olds for the CCC score and the curiosity and confidence sub-scales, which was consistent with trends in adolescent self-esteem found by Erol and Orth (2011). Understanding the development of career maturity based upon age can help understand at what age youth require the most support in acquiring the knowledge and skills needed to develop career maturity.

Although most analyses lacked significance, it is important to note that participants in this research study exceeded the high school norms for career maturity. The CMI scores revealed higher scores than the high school norms (Savickas, \& Porfeli, 2011) for the CCC score and three of the four sub-scales. The lower scores on the consultation sub-scale indicate a preference to make career choices with an independent relational style (Savickas, \& Porfeli, 2011). These higher scores reflect more advanced development among youth in the 4-H healthy lifestyles program and lead the researchers to conclude that the youth are indeed career mature, indicating a readiness to make informed career decisions and cope with career development tasks.

Even though results of this study lead researchers to conclude that youth in the Texas 4-H healthy lifestyles program are, indeed, career mature, further research can be conducted to expand beyond this one program area. The findings of this current study were limited by the population of youth involved in the Texas healthy lifestyles program and, therefore, cannot be generalized to youth involved in other programs within the Texas 4- $\mathrm{H}$ Youth Development Program. However, this study does provide evidence that the 4-H members involved in the 4-H healthy lifestyles program have the knowledge and skills to make intelligent, realistic career choices.

Youth are often involved in multiple organizations beyond 4- $\mathrm{H}$, some of which also strive to foster career readiness. Additionally, previous research has found that youth in 4-H learn about careers not only through participation in 4-H but also through non-4-H activities (Williams, et al., 2010). Therefore, it may be of value for future research to assess the career maturity of youth involved in other organizations. Future research that involves $4-\mathrm{H}$ members as well as 
youth not involved in the 4-H program may also be of benefit to show the impact 4-H involvement may have on youths' career maturity.

\section{Implications for Practice}

Although the researchers found the youth involved in the 4- $\mathrm{H}$ healthy lifestyles program to be career mature, there are some key recommendations that practitioners should keep in mind as they continue to foster career development among youth.

- Ensure career development is integrated into each 4-H project. Not only the healthy lifestyles program, but each 4-H project should give youth the opportunity to explore careers through various methods including activities, interactions, and special programs.

- Expand career exploration experiences. Lippman and Keith (2009) suggested youth are more likely to succeed in the workplace when they are given the opportunity to explore different careers. Albion and Fogarty (2002) also pointed out that career decisionmaking difficulties can be effectively relieved by providing access to relevant, up-to-date resources and information. Therefore, the 4-H program should give consideration to incorporating various career exploration experiences, such as career fairs and career camps, into the program.

Train adult volunteers to help in career choices, goal setting and interests. Training 4-H volunteers at the local level on how to promote careers related to $4-\mathrm{H}$ projects areas, methods of fostering career exploration, and the positive impact they can make by serving as a role model will benefit youth career development.

\section{References}

Albion, M.J., \& Fogarty, G.J. (2002). Factors influencing career decision making in adolescents and adults. Journal of Career Assessment, 10(1), 91-126.

Brown, S.D., \& Lent, R.W. (2005). Career development and counseling: Putting theory and research to work. Hoboken, NJ: Wiley.

Crites, J.O. (1973). Career maturity. Measurement in Education, 4(2), 1-8.

Dillman, D.A., Smyth, J.D., \& Christian, L.M. (2009). Internet, mail and mixed-mode surveys: The tailored design method ( $3^{\text {rd }}$ ed.). Hoboken, NJ: John Wiley \& Sons, Inc.

Erol, R.Y., \& Orth, U. (2011). Self-esteem development from age 14 to 30 years: A longitudinal study. Journal of Personality and Social Psychology, 101(3), 607-619.

King, S. (1989). Sex differences in a causal model of career maturity. Journal of Counseling and Development, 68(2), 208-215.

King, S. (1990). Background and family variables in a causal model of career maturity: Comparing hearing and hearing-impaired adolescents. The Career Development Quartlery, $38(3), 240-260$.

Lindner, J.R., Murphy, T.H., \& Briers, G.E. (2001). Handling nonresponse in social science research. Journal of Agricultural Education, 42(4), 43-53. 
Lippman, L., \& Keith, J. (2009). A developmental perspective on workplace readiness: Preparing high school students for success. Child Trends. Publication 2009-24.

Luzzo, D.A. (1993). Value of career-decision-making self-efficacy in predicting career-decisionmaking attitudes and skills. Journal of Counseling Psychology, 4O(2), 194-199.

Matulis, J.K., Hedges, L.E., Barrick, K., \& Smith, K.L. (1988). 4-H strikes a positive note. Journal of Extension, 26(1), Retrieved from www.joe.org/joe/1988spring/a5.php on June 8, 2011.

National 4-H Headquarters. (2001). 4-H national headquarters fact sheet: Mission mandates. Retrieved from http://www.csrees.usda.gov/nea/family/res/pdfs/Mission_Mandates.pdf

Ochs, L.A., \& Roessler, R.T. (2004). Predictors of career exploration intentions: A social cognitive career theory perspective. Rehabilitation Counseling Bulletin, 4ス4), 224-233.

Ohler, D.L., Levinson, E.M., \& Hays, G.M. (1996). The relationship between career maturity and congruence, consistency, and differentiation among individuals with and without learning disabilities. Journal of Employment Counseling, 33(2), 50-60.

Omvig, C.P., \& Thomas, E.G. (1977). The relationship between career education, sex, and career maturity of sixth and eighth grade pupils. Journal of Vocational Behavior, 11(3), 322331.

Patton, W., \& Creed, P.A. (2001). Developmental issues in career maturity and career decision status. The Career Development Quarterly, 49(4), 336-351.

Rockwell, S.K., Stohler, R.F., \& Rudman, L.E. (1984). How 4-H helps career development. Journal of Extension, 22(3), Retrieved from www.joe.org/joe/1984may/al.php on June 24, 2012.

Savickas, M.L. (1984). Career maturity: The construct and its measurement. The Vocational Guidance Quarterly, 32(4), 222-231.

Savickas, M.L., \& Porfelli, E.J. (2011). Revision of the career maturity inventory: The adaptability form. Journal of Career Assessment, 19(4), 355-374.

Stern, M., Norman, S.L., \& Zevon, M.A. (1991). Career development of adolescent cancer patients: A comparative analysis. Journal of Counseling Psychology, 38(4), 431-439.

Super, D.E. (1955). The dimensions and measurement of vocational maturity. Teachers College Record, 573), 151-163.

Super, D.E. (1990). A life-span, life-space approach to career development. In D. Brown \& L. Brooks (Eds.), Career choice and development ( $2^{\text {nd }}$ ed., pp. 197-261). San Francisco: JosseyBass.

Texas 4-H \& Youth Development. (2013, March 13). Healthy lifestyles. Retrieved from http://texas4-h.tamu.edu/healthy lifestyles 
United States Department of Labor. (2013a, March 24). Youth in transition. Retrieved from http://www.dol.gov/odep/topics/youth/ConnectingActivities.htm

United States Department of Labor. (2013b, March 25). Career preparation and work-based learning experiences. Retrieved from http://www.dol.gov/odep/categories/youth/career.htm

Westbrook, B.W., Cutts, C.C., Madison, S.S., \& Arcia, M. (1980). The validity of the Crites model of career maturity. Journal of Vocational Behavior, 16(3), 249-278.

Williams, B., Thompson, J., Taylor, T., \& Sanders, K.E. (2010). The impact of a youth development program on secondary students' career aspirations. Journal of Youth Development, 5(3), 76-89.

(C) Copyright of Journal of Youth Development Bridging Research and Practice. Content may not be copied or emailed to multiple sites or posted to a listserv without copyright holder's express written permission. Contact Editor at: patricia.dawson@oregonstate.edu for details. However, users may print, download or email articles for individual use. 